\begin{tabular}{|c|l|}
\hline Title & Evaluation of quality indexes of bending performance and hardness for hardwoods \\
\hline Author(s) & Teranishi, Masataka; Koizumi, A kio; Hirai, Takuro \\
\hline Citation & Journal of Wood Science, 54/5), 423-428 \\
https://doi.org/10.1007/310086-008-0969-1 \\
\hline Issue Date & 2008 10-25 \\
\hline Doc URL & http://hdl.handle.net/2115/35493 \\
\hline Rights & The original publication is available at www.springerlink.com \\
\hline Type & article (author version) \\
\hline File Information & koizumi.pdf \\
\hline
\end{tabular}

Instructions for use 


\title{
Evaluation of quality indexes of bending performance and hardness for hardwoods
}

\author{
by \\ Masataka Teranishi, Akio Koizumi, and Takuro Hirai \\ Graduate school of Agriculture, Hokkaido University
}

\begin{abstract}
Mechanical properties of 613 small clear specimens of 35 species (11 ring-porous hardwoods, 19 diffuse-porous hardwoods, and 5 softwoods) were evaluated. The aim of the study was to discuss indexes of wood quality that are easy to measure and that exhibit a high correlation with bending performance and hardness that are essential properties of hardwood products. The modulus of rigidity, dynamic modulus of elasticity, bending properties (modulus of elasticity, modulus of rupture, stress at the proportional limit, absorbed energy, Tetmajer's modulus), dynamic energy absorption by an impact bending test, compressive strength parallel to the grain, shear strength, partial bearing strength, and Brinell's hardness were measured. A high correlation was found between dynamic modulus of elasticity and static modulus of elasticity. Bending stress at the proportional limit was found to be approximately equivalent to the compressive strength parallel to the grain. Static energy absorption correlated with dynamic energy absorption. Tetmajer's modulus was found to be closely related to the ratio of the initial stiffness within the elastic range to the secant modulus at the maximum load. A high correlation was observed between Brinell's hardness and partial bearing strength. The difference in the regression coefficients obtained for these correlations between the species groups was small.
\end{abstract}

Key words: small clear specimen, quality index, strength characteristics, hardwood

\section{Introduction}

A large number of studies concerning the strength properties of softwood have been conducted because the structural members in timber constructions are composed of softwood ${ }^{1}$. The mechanical properties of some hardwood species that are used as finishing materials and in the manufacture of furniture and sports equipment also need to be clarified. The aim of this study is to propose quality indexes to evaluate the bending performance and hardness that are essential properties of various hardwood products. We focused on the properties of bending stiffness, bending strength, energy absorption capacity, toughness, and hardness. In order to propose quality indexes, we measured various mechanical properties and discussed the relationships between these properties. We also discussed the effects of the differences between the ring-porous hardwood, diffuse-porous hardwood, and softwood species groups on the relationships between the quality indexes.

\section{Materials and methods}

Thirty hardwood (11 ring-porous and 19 diffuse-porous) and 5 softwood species were tested (Table 1). Some of these wood samples were obtained from the undamaged section of trees wind-fallen by typhoon 0418 in Hokkaido University Campus. The shrinkage, density profile (determined by soft X-ray densitometry), and mechanical properties of these materials were reported ${ }^{2}$. Softwood specimens were tested for comparison with the hardwood samples. Cryptomeria japonica was selected as a low-density wood and Pseudotsuga menziesii, as a high-density wood. 
Small clear specimens with a cross section of $20 \times 20 \mathrm{~mm}$ and a length of $350 \mathrm{~mm}$ or $550 \mathrm{~mm}$ were cut from the air-dried lumber and used for the tests. When hardwoods are used for finishing materials or for the manufacture of furniture or sports equipment, defect-free members are usually used because the hardwood members used for these purposes are not as large as those used for timber constructions. Therefore, the properties of small clear specimens are considered to be reflective of the properties of the actual products. Cambial age ( $C A)$ was measured at the center of the cross section of each hardwood specimen. The average, standard deviation, maximum value, and minimum value of $C A$ were $24.5,20.8,111$, and 3, respectively. Watanabe et al. ${ }^{3}$ reported that the difference in wood quality between mature wood and juvenile wood for hardwood species was not as great as that observed for softwood species. In this study, all the results for the hardwood specimens were included.

By following JIS-Z2101, 285 specimens with a length of $550 \mathrm{~mm}$ were tested for impact bending (span of bending: $220 \mathrm{~mm})$. The absorbed energy in impact bending $\left(U_{\mathrm{d}}\right)$ was calculated by the loss of the potential energy of the pendulum of the tester $(98.0 \mathrm{~J})$, which is used to fracture the specimens, following impact.

The dynamic modulus of elasticity $\left(E_{\mathrm{d}}\right)$ and the modulus of rigidity $(G)$ of all specimens, including the sections undamaged by the impact bending tests, were determined by the longitudinal vibration method and a torsional test ${ }^{4}$, respectively. Static bending tests were then performed following JIS-Z2101; the static modulus of elasticity $\left(E_{\mathrm{b}}\right)$, stress at the proportional limit $\left(\sigma_{\mathrm{bp}}\right)$, modulus of rupture $(M O R)$, absorbed energy up to the maximum load in static bending $\left(U_{\mathrm{b}}\right)$, and Tetmajer's modulus $(T M)^{5,6}$ were evaluated. $\sigma_{\mathrm{bp}}$ is defined as the stress that developed when the initial stiffness declined by $2 \%$. TM is the ratio of the integration value of the load-deflection curves obtained by the bending tests up to the maximum load (area of OCD in Fig. 1) to the product of the maximum load and the deflection at the maximum load (area of OACD).

After the bending tests, 4 test specimens were cut from the undamaged sections; the compressive strength parallel to the grain (CS), shear strength concerning the longitudinal-radial plane (SS), partial bearing strength (PBS) and Brinell's hardness $(H)$ of these specimens was determined according to JIS-Z2101. PBS was defined as the stress that developed when the specimen was compressed under a bearing plate to $19 \mathrm{~mm}$ (95\% of the height of the specimen). The average moisture content of the test specimens was $12.3 \%$.

\section{Results and discussion}

\section{Average ring width, specific gravity, and dynamic modulus of elasticity}

Average ring width $(A R W)$, wood density $(W D)$, and dynamic modulus of elasticity $\left(E_{\mathrm{d}}\right)$ are the simplest indexes of the mechanical properties of wood. The correlations between these indexes and the mechanical properties were examined (Table 2). With regard to the ring-porous hardwoods, specimens with a broader $A R W$ showed higher values of stiffness ( $E$ and $G$ ) and strength ( $\sigma_{\mathrm{bp}}, M O R, C S, S S$, and $P B S$ ) than those with a narrower $A R W$. This is because ring width is positively correlated with wood density for ring-porous hardwoods ${ }^{7}$. On the other hand, the relationship between $A R W$ and mechanical properties for diffuse-porous hardwoods was not clear.

The correlations between $W D$ and $E_{\mathrm{b}}$ and between $W D$ and $M O R$ for hardwoods were lower than the corresponding values for softwoods (Table 2, Fig. 2). This is because specific $E_{\mathrm{b}}$ (the ratio of $E_{\mathrm{b}}$ to specific gravity) for hardwoods, particularly for diffuse-porous hardwoods, varied considerably according to the species. The specific $E_{\mathrm{b}}$ varied from $14.9 \mathrm{GPa}$ for Sorbus commixta to $26.1 \mathrm{GPa}$ for Tilia japonica. The variability for hardwood species may be attributed to the difference in composition ratio of various types of cells such as rays. It is difficult to estimate mechanical properties precisely from wood density for 
hardwood species.

The correlation between $E_{\mathrm{d}}$ and $M O R$ was high, as is generally observed. The highest correlation between these indexes was found in softwood species, followed by ring-porous hardwood and diffuse-porous hardwood (Table 2).

\section{Bending stiffness}

Stiffness is one of the most important bending performance properties. Modulus of elasticity, which is a measure of stiffness, can be determined by both the bending test $\left(E_{\mathrm{b}}\right)$ and the longitudinal vibration test $\left(E_{\mathrm{d}}\right)$. The longitudinal vibration test seems to be more simple and convenient than the bending test. A high correlation was observed between $E_{\mathrm{b}}$ and $E_{\mathrm{d}}$ in all 3 species groups (Fig. 3, Table 3). $E_{\mathrm{b}}$ can be estimated from the results of the impact bending test regardless of the species group.

$E_{\mathrm{d}}$ values were $27 \%$ higher than those of $E_{\mathrm{b}}$; a part of this difference was attributed to the shear deflection in the center-load bending tests. The approximate values of modulus of elasticity without the effect of shear deflection $\left(E^{\prime}\right)$ were estimated from Eq.1.

$$
E^{\prime}=E_{\mathrm{b}}(1+\alpha)
$$

where $\alpha=\frac{6}{5}\left(\frac{E_{\mathrm{b}}}{G}\right)\left(\frac{h}{l}\right)^{2} ; l$, span of bending; $h$, height of the specimen.

$E_{\mathrm{d}}$ values were $20 \%$ higher than those of $E^{\prime}$ (Fig. 3). The difference between $E^{\prime}$ and $E_{\mathrm{d}}$ could be attributed to the viscoelastic behavior of wood.

\section{Bending strength}

With regard to strength design, $\sigma_{\mathrm{bp}}$ as well as $M O R$ are important because allowable bending strength should be based on the elastic limit, because the compression failure will occur on the compression side of a beam above the elastic limit. The correlation between $C S$ and $\sigma_{\text {bp }}$ was sufficiently high for all the specimens except for diffuse-porous hardwood, and $\sigma_{\mathrm{bp}}$ values were found to be equivalent to CS (Fig. 4, Table 3).

\section{Energy absorption capacity}

Impact bending strength, which is related to dynamic energy absorption capacity $\left(U_{\mathrm{d}}\right)$, is essential in sports equipments such as baseball bats ${ }^{8}$. The possibility of estimating $U_{\mathrm{d}}$ from $U_{\mathrm{b}}$ determined by the static bending test was examined.

Although the variation in the absorbed energy for individual specimens was large particularly for diffuse-porous hardwood, a high correlation was observed between the $U_{\mathrm{d}}$ and $U_{\mathrm{b}}$ values averaged for species (Fig. 5, Table 3). The Static bending test can be used instead of the impact bending test to estimate $U_{\mathrm{d}} . U_{\mathrm{d}}$ was two times larger than $U_{\mathrm{b}}$, approximately. In addition to the difference between dynamic and static behavior and the difference in the span of bending, this result could be attributed to the fact that $U_{\mathrm{b}}$ was determined as the integrated value of the load-deflection curve up to the maximum load. Actually, the absorbed energy includes the energy absorbed after the maximum load.

\section{Toughness}

Kollmann and Côté ${ }^{5}$ reported that TM for standard grade lumber was 0.7. TMs for the boxed-heart lumber of Cryptomeria japonica and for the small clear specimens of Cunninghamia lanceolata were reported as 0.52 and 0.64-0.66, respectively ${ }^{6,9}$.

The average TMs obtained for ring-porous hardwood and diffuse-porous hardwood were 0.71 and 0.72 , 
respectively. Based on the assumption that bending follows an elastic-plastic behavior, $T M$ can be replaced with the ratio of the area of OBCD to the area of OACD (Fig. 1) and is compatible with the ratio of the initial stiffness $\left(m_{1}=P_{\max } / \delta_{1}\right)$ to the secant modulus at maximum load $\left(m_{2}=P_{\max } / \delta_{2}\right)$ as shown in Eq. 2.

$$
\frac{m_{2}}{m_{1}} \approx 2(1-T M)
$$

The regression equation between $T M$ and the stiffness ratio $\left(m_{2} / m_{1}\right)$ almost agreed with Eq. 2 in all 3 species groups (Fig. 6, Table 3). Consequently, both $T M$ and the stiffness ratio could be used as toughness indexes.

\section{Hardness and bearing performance}

Scratches on tabletops, dents in floorboards, and the rebound characteristics of baseball bats reflect the hardness of wood. Bearing performance (compression perpendicular to the grain) is an essential property of furniture joints such as mortise and tenon joints. $H$ and $P B S$ are expected to be closely related because the methods specified in JIS-Z2101 for testing these 2 properties are similar.

A high correlation was observed between $H$ and $P B S$ for hardwood species (Fig. 7). Although the $H$ value was an average of 3 measurements per specimen, the coefficients of variation for $H$ were considerably larger than those for PBS for ring-porous hardwoods (Table 4). This is because $H$ might be affected by the density variation within an annual ring. The diameter of a steel ball embedded in the specimens at the embedded depth of $0.32 \mathrm{~mm}$ was approximately $2.4 \mathrm{~mm}$ and was smaller than the ring width in most cases.

\section{Conclusions}

Quality indexes of the bending characteristics and hardness of hardwoods were discussed. The obtained results are as follows.

1. High correlations were observed between $E_{\mathrm{d}}$ and $E_{\mathrm{b}}, \sigma_{\mathrm{bp}}$ and $C S, U_{\mathrm{d}}$ and $U_{\mathrm{b}}, T M$ and ratio of the initial stiffness to the secant modulus at maximum load, and between $H$ and $P B S$.

2. Each index of these relationships can be estimated from the other indexes in all 3 species groups (ring-porous hardwood, diffuse-porous hardwood, and softwood) because the difference in the regression coefficients obtained for these correlations between the species groups was small.

\section{References}

1. Iijima Y (2007) Standardization of testing and evaluation method for full-size structural timber strength in Japan (in Japanese). Mokuzai Gakkaishi 53: 63-71

2. Koizumi A, Teranishi M, Hirai T (2007) Shrinkage and mechanical properties of wood sampled from the trees planted in Hokkaido University (in Japanese). Res. Bull. Hokkaido Univ. For. 64: 91-104

3. Watanabe H, Matsumoto T, Hayashi H (1966) Studies on juvenile wood 3 (in Japanese). Mokuzai Gakkaishi 12: 259-265

4. Koizumi A, Takata K, Yamashita K, Nakada R (2003) Anatomical characteristics and mechanical properties of Larix sibirica grown in south-sentral Siberia. IAWA J. 24: 355-370

5. Kollmann, FFP, Côté, WA (1968) Principals of solid wood science and technology 1. Springer, New York, pp 364-265

6. Kijidani Y, Kitahara R (2005) Effect of basic wood properties on strength and stiffness in bending of 
Cryptomeria japonica timbers (in Japanese). J. Soc. Mat. Sci. 54: 377-380

7. Kollmann, FFP, Côté, WA (1968) Principals of solid wood science and technology 1. Springer, New York, pp 178-179

8. Miyajima H (1966) Growth and wood quality of aodamo (Japanese ash tree) grown in Hidaka District Hokkaido (in Japanese). Res. Bull. College Experiment For. Hokkaido Univ. 36: 421-450

9. Liu Y, Nakayama Y, Kanagawa Y, Fujiwara S (1999) Bending work of plantation grown Chinese fir (Cunninghamia lanceolata Hook.) (in Japanese). Mokuzai Gakkaishi 45: 359-366 
Table 1. Species and number of specimens

\begin{tabular}{|c|c|c|c|c|}
\hline \multirow[b]{3}{*}{ Species group } & \multirow[b]{3}{*}{ Species } & \multicolumn{3}{|c|}{ Number of specimens } \\
\hline & & \multirow[b]{2}{*}{ Trees } & \multicolumn{2}{|c|}{ Small clear specimens } \\
\hline & & & $\begin{array}{c}\text { Static } \\
\text { bendig } \\
\text { test }\end{array}$ & $\begin{array}{c}\text { Impact } \\
\text { bending } \\
\text { test }\end{array}$ \\
\hline \multirow{11}{*}{$\begin{array}{l}\text { Hardwoods } \\
\text { (Ring-porous) }\end{array}$} & Ailanthus altissima & 7 & 37 & - \\
\hline & Carya ovalis & 1 & 12 & - \\
\hline & Fraxinus americana & 14 & 41 & 41 \\
\hline & Fraxinus lanuginosa & 23 & 57 & 57 \\
\hline & Fraxinus pennsylvanica & 3 & 14 & 9 \\
\hline & Gleditsia triacanthos & 1 & 7 & - \\
\hline & Kalopanax pictus & 1 & 3 & - \\
\hline & Phellodendron amurense & 1 & 2 & - \\
\hline & Quercus rubra & 1 & 4 & - \\
\hline & Robinia pseudoacacia & 6 & 27 & - \\
\hline & Ulmus davidiana var. japonica & 6 & 27 & - \\
\hline \multirow{19}{*}{$\begin{array}{c}\text { Hardwoods } \\
\text { (Diffuse-porous) }\end{array}$} & Acer mono & 11 & 34 & 28 \\
\hline & Acer negundo & 5 & 38 & - \\
\hline & Acer saccharum & 19 & 54 & 54 \\
\hline & Aesculus glabra & 1 & 5 & - \\
\hline & Alnus japonica & 2 & 20 & - \\
\hline & Betula platyphylla var. japonica & 1 & 6 & - \\
\hline & Juglans ailanthifolia & 1 & 7 & - \\
\hline & Juglans regia & 1 & 6 & - \\
\hline & Magnolia denudata & 1 & 9 & - \\
\hline & Magnolia kobus var. borealis & 1 & 7 & - \\
\hline & Malus pumila var. domestica & 3 & 20 & - \\
\hline & Ostrya japonica & 1 & 5 & - \\
\hline & Populus nigra var. italica & 1 & 7 & - \\
\hline & Populus sieboldii & 3 & 7 & 3 \\
\hline & Prunus padus & 1 & 6 & - \\
\hline & Prunus sargentii & 2 & 7 & - \\
\hline & Salix hultenii var. augustifolia & 3 & 9 & 5 \\
\hline & Sorbus commixta & 1 & 11 & - \\
\hline & Tilia japonica & 2 & 11 & 5 \\
\hline \multirow[t]{6}{*}{ Softwoods } & Abies sachalinensis & 1 & 8 & 8 \\
\hline & Cryptomeria japonica & 6 & 51 & 39 \\
\hline & Ginkgo biloba & 3 & 12 & - \\
\hline & Pinus bungeana & 1 & 3 & - \\
\hline & Pseudotsuga menziesii & - & 39 & 36 \\
\hline & Total & 135 & 613 & 285 \\
\hline
\end{tabular}


Table 2. Coefficient of correlations between simple quality indexes and mechanical properties that were significant at $1 \%$ level

\begin{tabular}{|c|c|c|c|c|c|c|c|c|c|c|c|c|}
\hline & $W D$ & $E_{\mathrm{d}}$ & $E_{\mathrm{b}}$ & $G$ & $M O R$ & $\sigma_{\mathrm{bp}}$ & $U_{\mathrm{b}}$ & $T M$ & CS & SS & $P B S$ & $H$ \\
\hline \multicolumn{13}{|c|}{ Ring-porous hardwoods } \\
\hline$A R W$ & 0.29 & 0.39 & 0.41 & 0.62 & 0.44 & 0.43 & 0.26 & n.s. & 0.44 & 0.37 & 0.33 & 0.27 \\
\hline$W D$ & & 0.75 & 0.73 & 0.72 & 0.75 & 0.63 & 0.63 & 0.29 & 0.72 & 0.76 & 0.74 & 0.65 \\
\hline$E_{\mathrm{d}}$ & & & 0.97 & 0.71 & 0.85 & 0.77 & 0.67 & 0.44 & 0.78 & 0.61 & 0.54 & 0.51 \\
\hline \multicolumn{13}{|c|}{ Diffuse-porous hardwoods } \\
\hline$A R W$ & 0.27 & n.s. & n.s. & 0.21 & n.s. & n.s. & 0.41 & 0.33 & n.s. & n.s. & n.s. & 0.23 \\
\hline$W D$ & & n.s. & n.s. & 0.62 & 0.55 & 0.35 & 0.57 & n.s. & 0.43 & 0.78 & 0.85 & 0.83 \\
\hline$E_{\mathrm{d}}$ & & & 0.95 & n.s. & 0.69 & 0.68 & n.s. & n.s. & 0.69 & n.s. & n.s. & n.s. \\
\hline
\end{tabular}

Softwoods

$\begin{array}{ccccccccccccc}A R W & -0.44 & -0.42 & -0.43 & \text { n.s. } & -0.42 & -0.31 & -0.31 & -0.22 & -0.43 & -0.32 & -0.33 & -0.32 \\ W D & & 0.79 & 0.80 & 0.73 & 0.92 & 0.77 & 0.71 & 0.19 & 0.92 & 0.84 & 0.74 & 0.78 \\ E_{\mathrm{d}} & & & 0.99 & \text { n.s. } & 0.94 & 0.92 & 0.50 & 0.28 & 0.94 & 0.59 & 0.46 & 0.62\end{array}$

Overall

\begin{tabular}{ccccccccccrrr}
$A R W$ & n.s. & n.s. & n.s. & 0.23 & n.s. & n.s. & 0.19 & n.s. & n.s. & n.s. & n.s. & n.s. \\
$W D$ & & 0.54 & 0.54 & 0.78 & 0.77 & 0.41 & 0.73 & 0.47 & 0.69 & 0.89 & 0.86 & 0.81 \\
$E_{\mathrm{d}}$ & & & 0.99 & n.s. & 0.83 & 0.79 & 0.34 & 0.17 & 0.85 & 0.49 & 0.48 & 0.5 \\
\hline
\end{tabular}

$A R W$, Average ring width; $W D$, Wood density; $E_{\mathrm{d}}$, Dynamic modulus of elasticity; $E_{\mathrm{b}}$, Static modulus of elasticity; $G$, Modulus of rigidity; $M O R$, Modulus of rupture; $\sigma_{\mathrm{bp}}$, Bending stress at the proportional limit; $U_{\mathrm{b}}$, Absorbed energy in static bending; TM, Tetmajor's modulus; CS, Compressive strength parallel to the grain; SS, Shear strength; PBS, Partial bearing strength; $H$, Brinell's hardness;

n.s., not significant at $1 \%$ level 
Table 3. Regression coefficinets and the coefficients of determination $\left(R^{2}\right)$ for the considered relationships

\begin{tabular}{|c|c|c|c|c|c|}
\hline$X^{\text {a) }}$ & $Y^{\mathrm{a})}$ & Species group & $a^{\text {a) }}$ & $b^{\text {a) }}$ & $R^{2}$ \\
\hline \multirow[t]{4}{*}{$E_{\mathrm{d}}$} & $E_{\mathrm{b}}$ & Ring-porous hardwoods & 0.785 & - & 0.96 \\
\hline & & Diffuse-porous hardwoods & 0.789 & - & 0.94 \\
\hline & & Softwoods & 0.784 & - & 0.98 \\
\hline & & Overall & 0.786 & - & 0.97 \\
\hline \multirow[t]{4}{*}{$C S$} & $\sigma_{\mathrm{bp}}$ & Ring-porous hardwoods & 0.903 & - & 0.71 \\
\hline & & Diffuse-porous hardwoods & 0.867 & - & 0.46 \\
\hline & & Softwoods & 1.050 & - & 0.81 \\
\hline & & Overall & 0.935 & - & 0.64 \\
\hline \multirow[t]{4}{*}{$U_{\mathrm{b}}$} & $U_{\mathrm{d}}$ & Ring-porous hardwoods & 1.91 & - & 0.31 \\
\hline & & Diffuse-porous hardwoods & 2.06 & - & 0.15 \\
\hline & & Softwoods & 2.13 & - & 0.76 \\
\hline & & Overall & 1.99 & - & 0.54 \\
\hline \multirow[t]{4}{*}{$T M$} & $m_{1} / m_{2}$ & Ring-porous hardwoods & -2.09 & 1.95 & 0.92 \\
\hline & & Diffuse-porous hardwoods & -2.01 & 1.91 & 0.81 \\
\hline & & Softwoods & -2.22 & 2.08 & 0.97 \\
\hline & & all & -2.21 & 2.05 & 0.91 \\
\hline \multirow[t]{4}{*}{ PBS } & $H$ & Ring-porous hardwoods & 1.27 & - & 0.69 \\
\hline & & Diffuse-porous hardwoods & 1.20 & - & 0.83 \\
\hline & & Softwoods & 1.26 & - & 0.37 \\
\hline & & Overall & 1.25 & - & 0.82 \\
\hline
\end{tabular}

a) $Y=a X+b$ for $T M$ and $m_{1} / m_{2}, \quad Y=a X$ for the other relationships 
Table 4. coefficients of variation for hardness $(H)$ and partial bearing strength (PBS)

coefficients of variation

\begin{tabular}{ccc} 
& \multicolumn{2}{c}{$(\%)$} \\
\cline { 2 - 3 } & $H$ & $P B S$ \\
\hline Ring-porous hardwoods & 22.8 & 13.5 \\
Diffuse-porous hardwoods & 17.5 & 13.3 \\
Softwoods & 18.6 & 16.5 \\
\hline
\end{tabular}




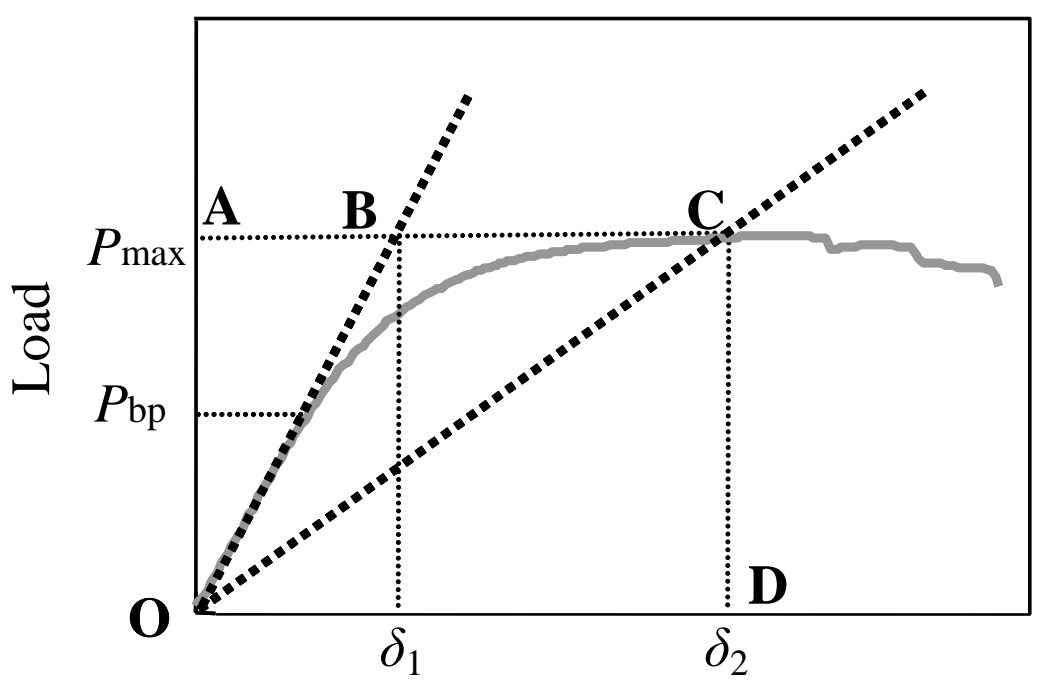

Mid-span deflection

Fig. 1 An example of load-deflection curves obtained from the bending tests.

$P_{\max }$, maximum load; $P_{\mathrm{bp}}$, proportional-limit load; $\delta_{1}$, A, coordinate point $\left(0, P_{\max }\right)$; B, coordinate point $\left(\delta_{1}, P_{\max }\right)$; C, coordinate point $\left(\delta_{2}, P_{\max }\right)$; D, coordinate point $\left(\delta_{2}, 0\right)$ 

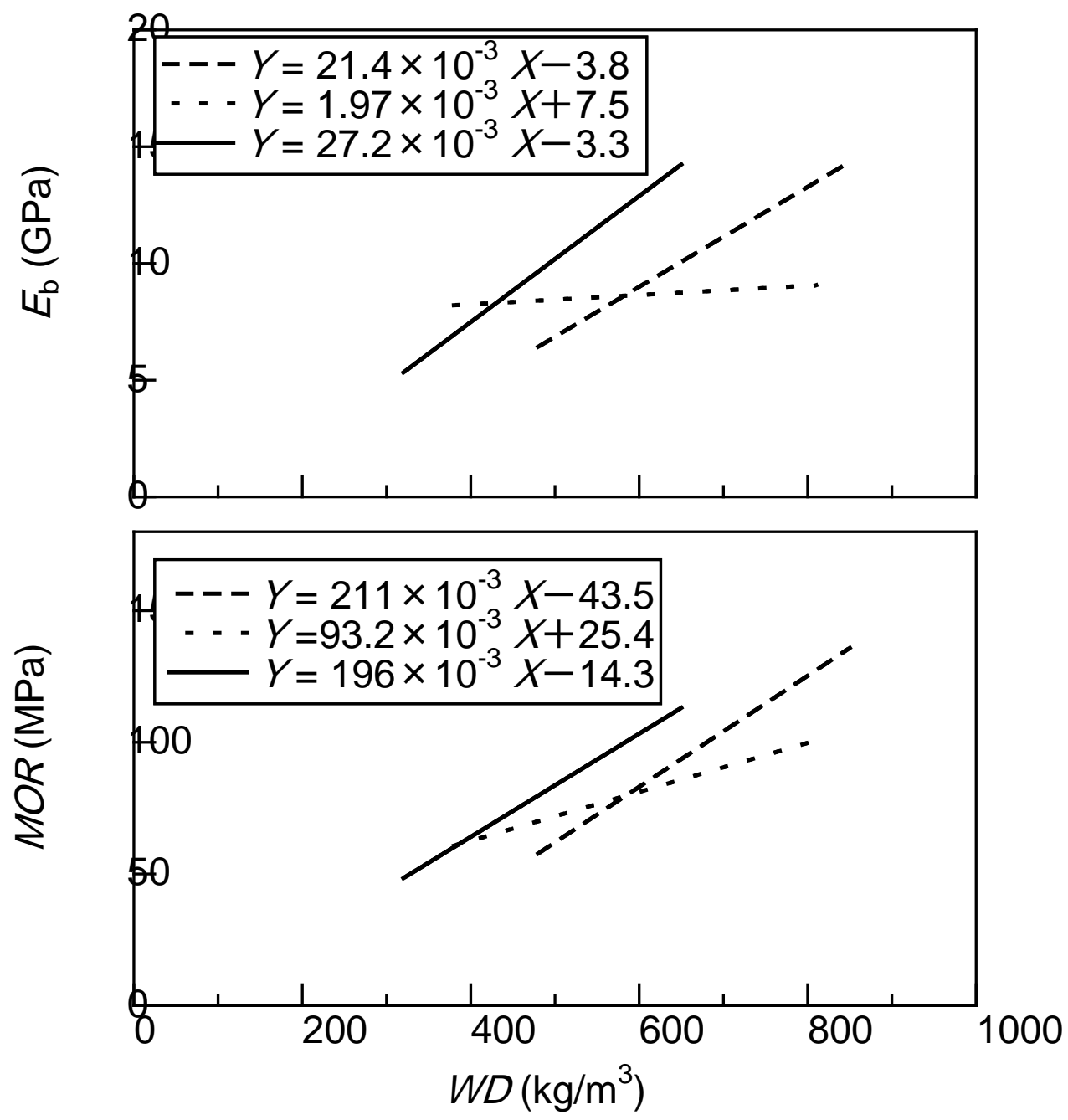

Fig. 2. Regression lines for the relationship between wood density $(W D)$ and static modulus of elasticity $\left(E_{\mathrm{b}}\right)$ (top) and between $W D$ and modulus of rupture (MOR) (bottom).

Legend - - - Ring-porous hardwoods, ……. Diffuse-porous hardwoods, — Softwoods 


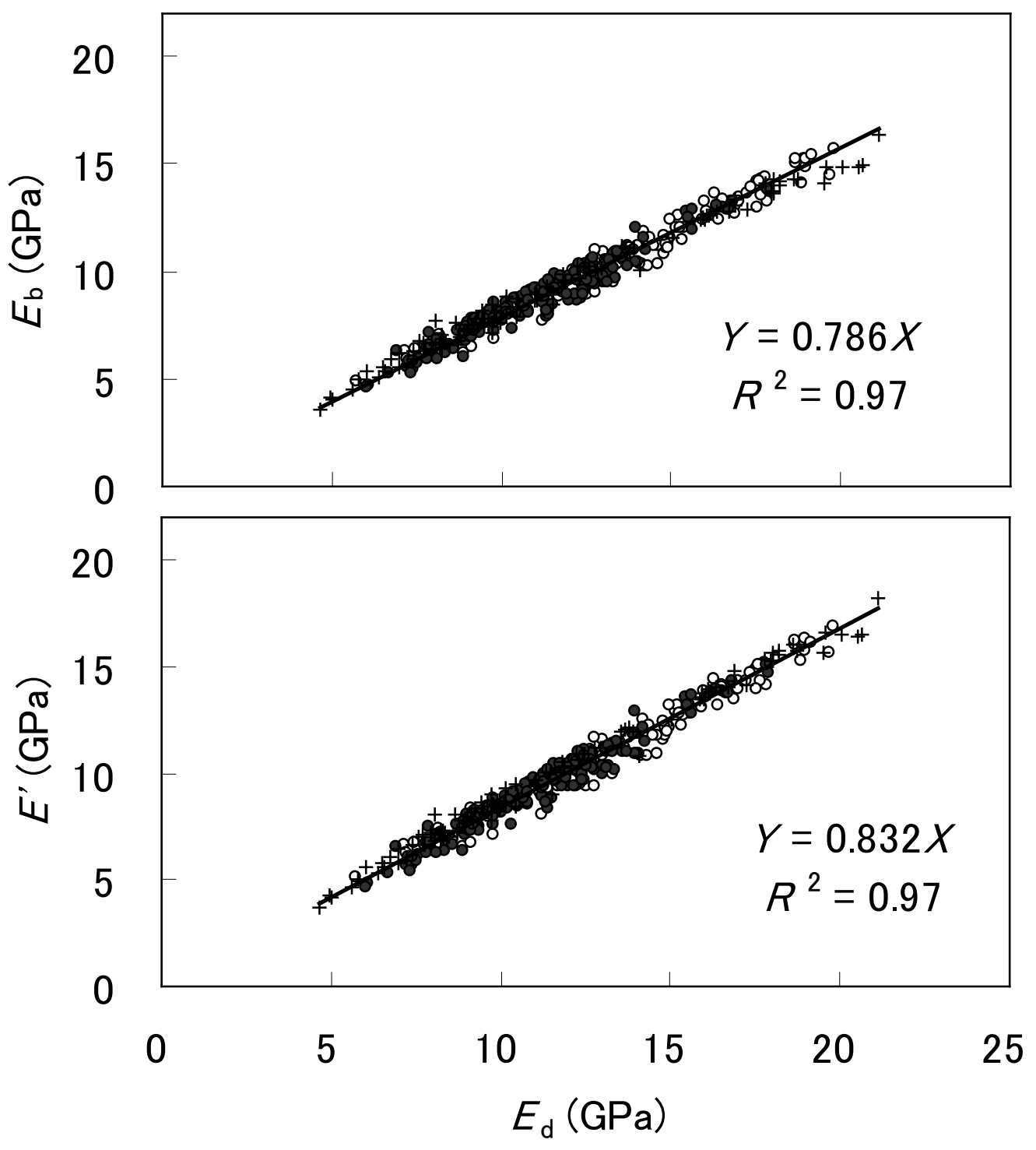

Fig. 3. Correlation between dynamic modulus of elasticity $\left(E_{\mathrm{d}}\right)$ and static modulus of elasticity ( $\left.E_{\mathrm{b}}\right)$ (top) and between $E_{\mathrm{d}}$ and the static modulus of elasticity without the effect of shear deflection ( $E^{\prime}$ ) (bottom).

Legend $\bigcirc$ Ring-porous hardwoods, • Diffuse-porous hardwoods, + Softwoods 


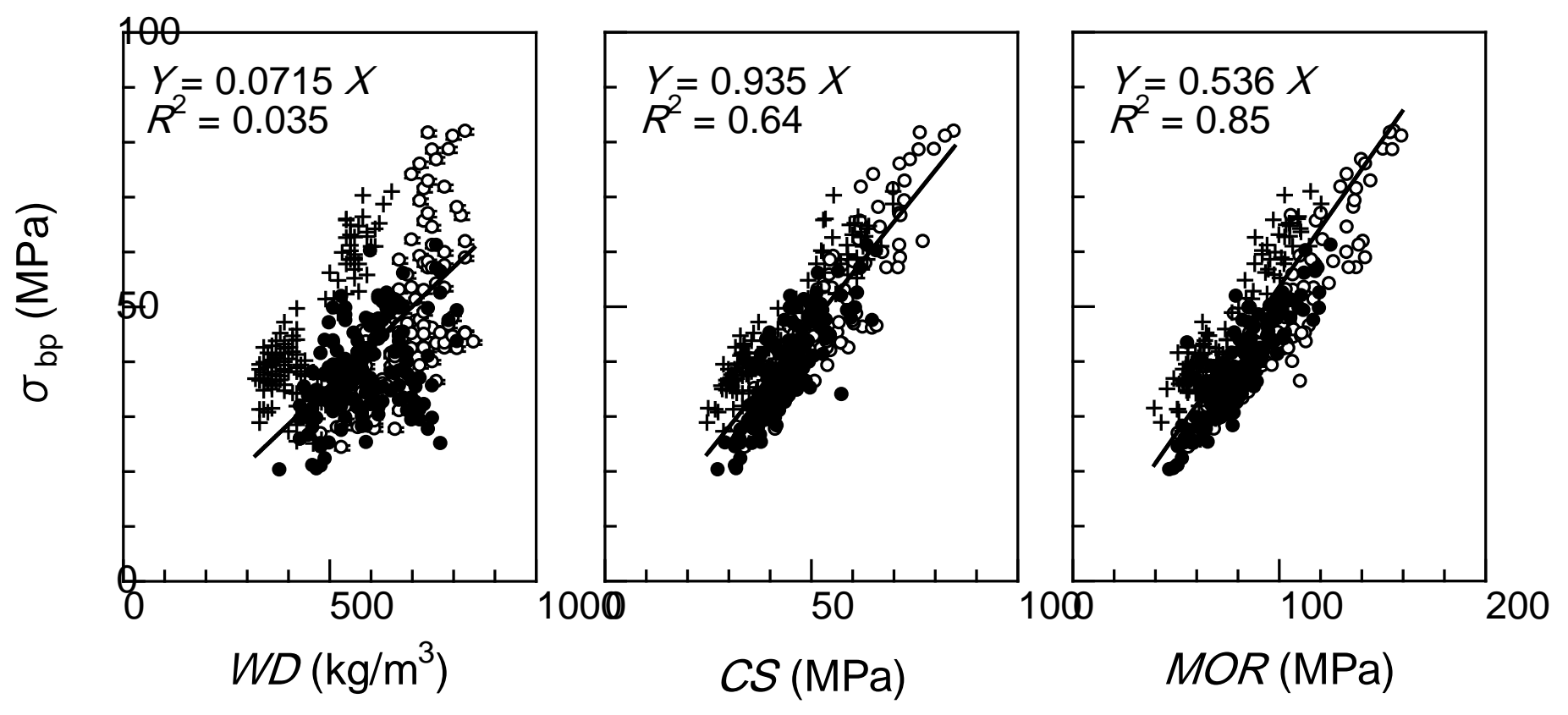

Fig. 4. Correlations of stress at the proportional limit $\left(\sigma_{\mathrm{bp}}\right)$ with $W D, C S$, and MOR.

Legend ○ Ring-porous hardwoods, • Diffuse-porous hardwoods, + Softwoods 


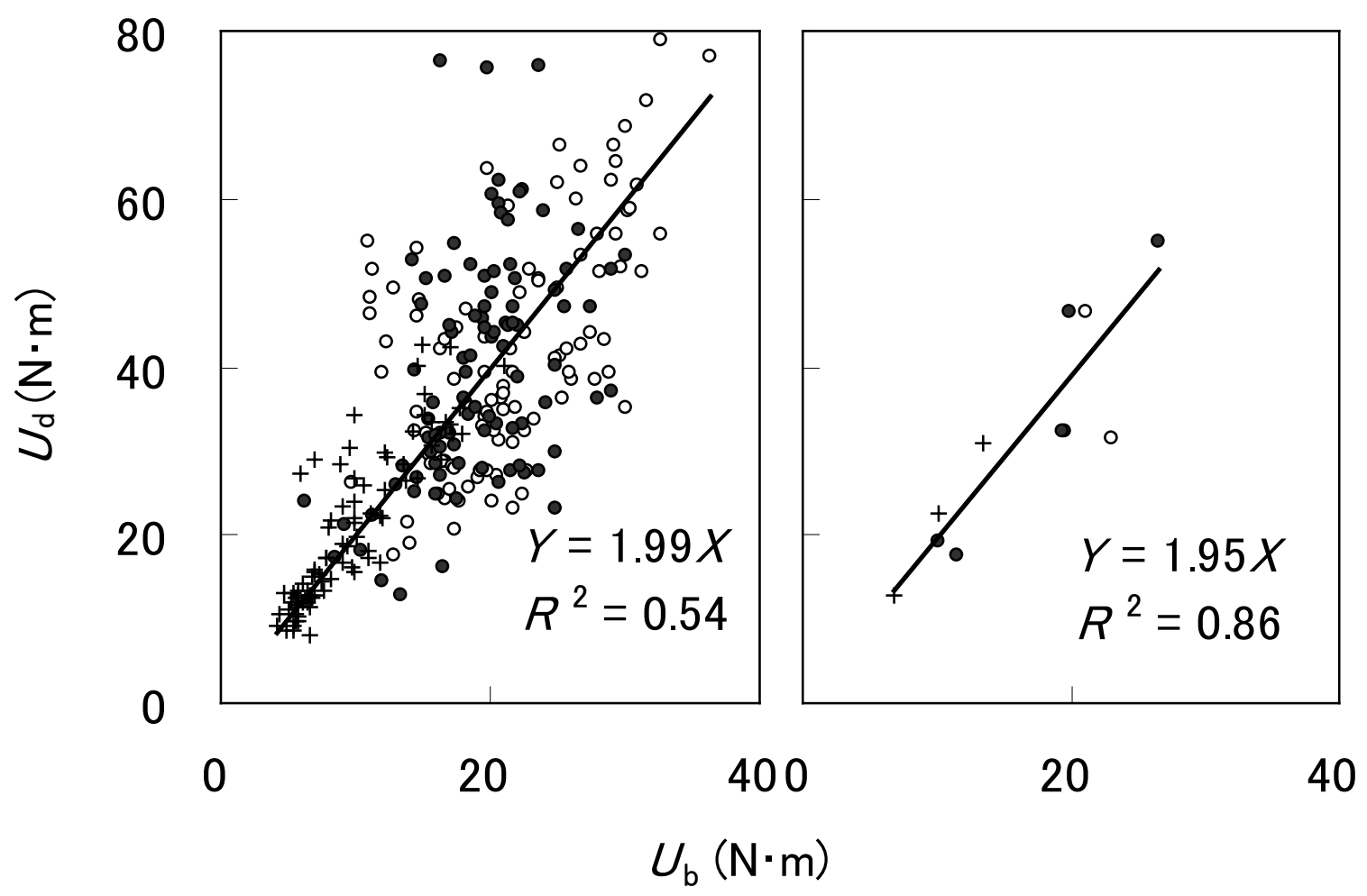

Fig. 5. Correlation between static energy absorption capacity $\left(U_{\mathrm{b}}\right)$ and dynamic energy absorption capacity $\left(U_{\mathrm{d}}\right)$. left: individual specimens, right: values averaged for species.

Legend ○ Ring-porous hardwoods, • Diffuse-porous hardwoods, + Softwoods 


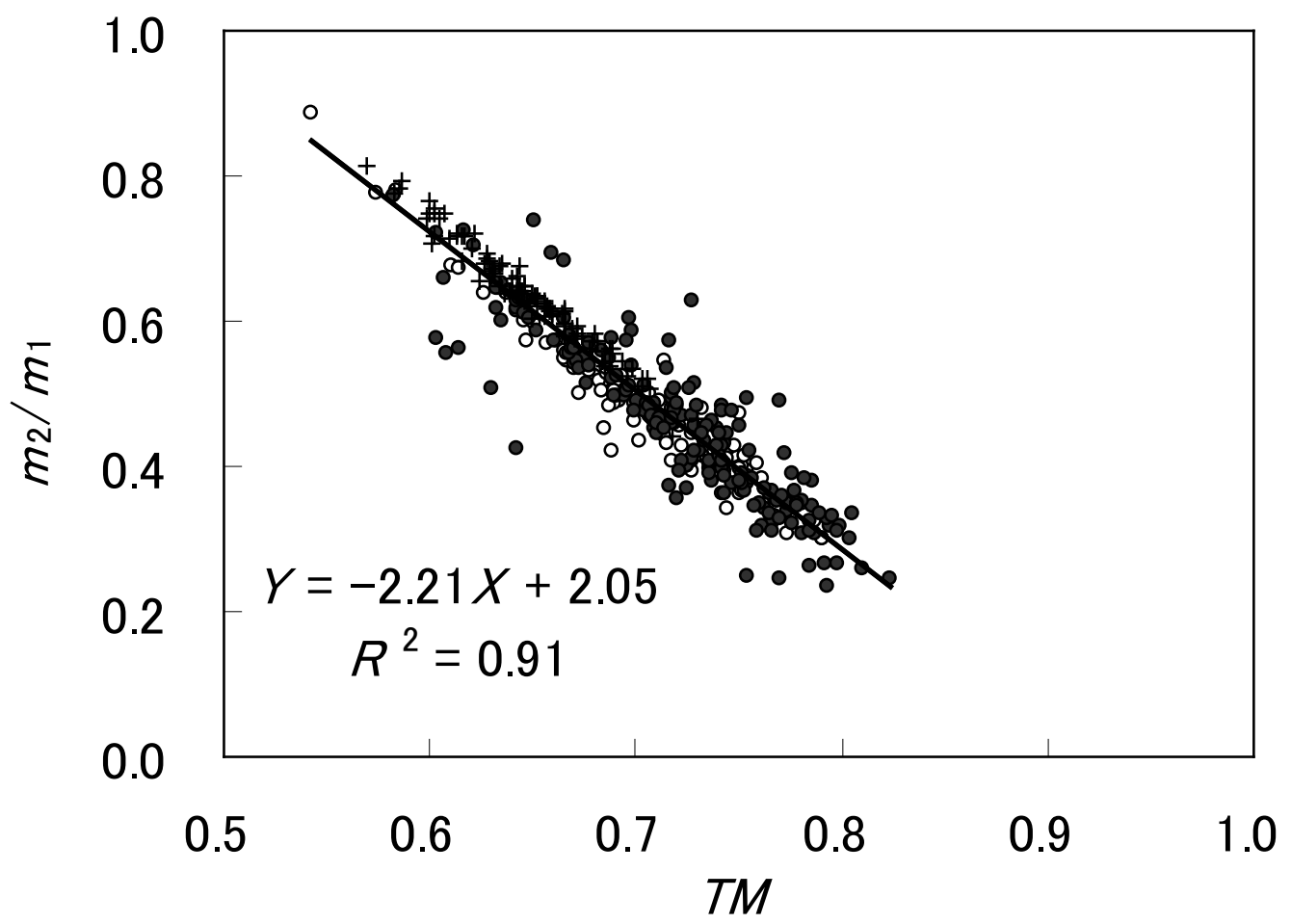

Fig. 6. Relationship between Tetmajer's modulus (TM) and ratio of the initial stiffness to the secant modulus at maximum load $\left(m_{2} / m_{1}\right)$.

Legend ○ Ring-porous hardwoods, • Diffuse-porous hardwoods, + Softwoods 


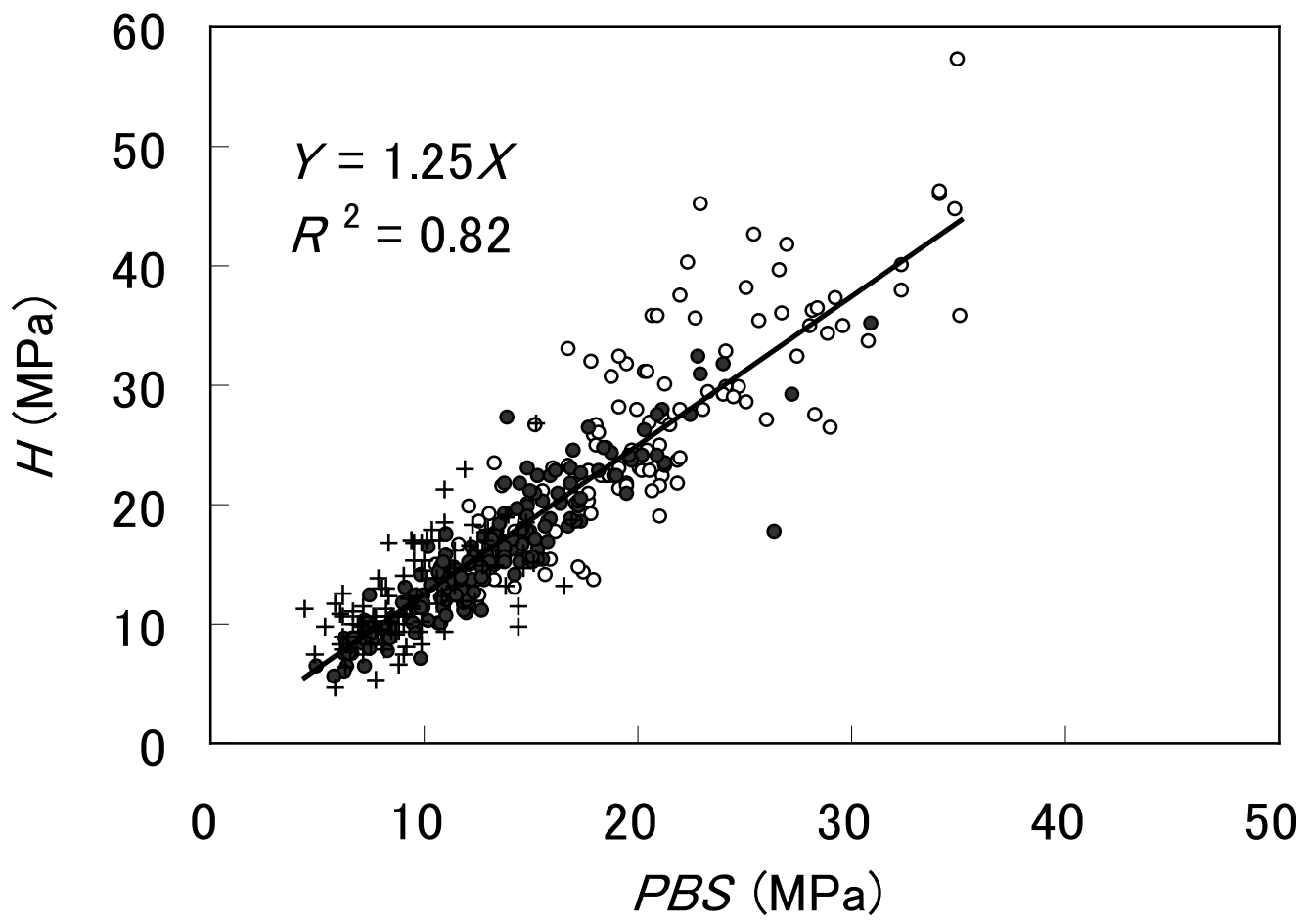

Fig. 7. Relationship between partial bearing strength (PBS) and Brinell's hardness $(H)$.

Legend ○ Ring-porous hardwoods, • Diffuse-porous hardwoods, + Softwoods 